Mirostaw S. Wróbel

The John Paul II Catholic University of Lublin, Poland

\title{
The Rabbinic Anti-Gospel in the Context of the Polemic between the Synagogue and the Church
}

\begin{abstract}
This article tries to find the answers to the following questions: Can one find, in the Rabbinic writings (the Tosefta, Jerusalem Talmud and Babylonian Talmud), some texts that refer to Jesus and His followers? What is their nature? Do they include antiChristian undertones and constitute a specific Rabbinic anti-gospel: the rabbis' wellthought and thorough reaction to the content included in the Gospels? The author in his answers used the detailed research presented in his latest monograph entitled Jesus and His Followers in the Talmud. A Textological, Historical and Sociological Analysis, Lublin 2013. His investigation leads him to the conclusion that in Talmudic narratives Rabbis created a specific anti-gospel which was initially transmitted verbally and then written down in various contexts of their works. The aim of this anti-gospel is to challenge the authority of Jesus of Nazareth as the Son of God and the Messiah from the house of David. Rabbinic narratives wish to show in a clear way that Jesus must not usurp any messianic and divine prerogatives. In the earlier times rabbis warned Jewish community against magic power and the attractiveness of the doctrine advocated by heretics. Subsequent rabbis showed the weakness and stupidity of heretical teaching, whose contradictions and lack of logic were easy to disprove by making use of proper argumentation. Jewish sages wished to prove the superiority of the Rabbinic doctrine and the biblical presentation they offered, over the Christian faith.
\end{abstract}

\section{Keywords}

Rabbinic sources, anti-gospel, polemic between Synagogue and Church.

Can one find in the Rabbinic writings (the Tosefta, Jerusalem Talmud and Babylonian Talmud) some texts that refer to Jesus and His followers? What is their nature? Do they include anti-Christian hints and constitute a specific 
The Person and the Challenges
Volume 4(2014) Number 2, $p .45-59$

Rabbinic anti-gospel: the rabbis' well-thought and thorough reaction to the content included in the Gospels? In this article we shall try to formulate answers to these questions which, offer, in a synthetic manner, the detailed research presented in my latest monograph entitled Jesus and His Followers in the Talmud. A Textological, Historical and Sociological Analysis ${ }^{1}$. In this article we shall turn our attention to three issues: (1) The nature of Rabbinic texts regarding Jesus and His followers; (2) The context of Rabbinic passages in the polemic between the Synagogue and the Church; (3) The features of the Rabbinic anti-gospel.

\section{The nature of Rabbinic texts on the matter of Jesus and His followers}

More than 100 years ago in the introduction to his book entitled Jesus die Häretiker und die Christen nach den ältesten jüdischen Angaben Prof. Herman I. Strack wrote: "There still prevail many false opinions about the number and importance of references to Jesus and His followers in Rabbinic

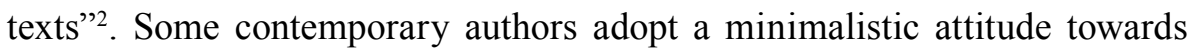
these Rabbinic texts - mainly by depreciating their meaning and historical value $^{3}$, by consciously leaving them unsaid or by distorting their sense. As an example, one can take The Lexicon of Christian-Jewish Dialogue by Jakub Petuchowski and Clemens Thoma, in which the definition of the entry "Jesus of Nazareth" leaves Rabbinic texts about Jesus and His followers unmentioned. The authors conclude that what is said about Jesus in Talmudic writings is not historical but a reflection of the anti-Semitic attitude of the Church. Jesus is

1 M. S. Wróbel, Jesus and His Followers in the Talmud. A Textological, Historical and Sociological Analysis, Lublin 2013.

2 H. L. Strack, Jesus die Häretiker und die Christen nach den ältesten jüdischen Angaben, Leipzig 1910, p. 4*-5*: "Über die Zahl wie die Bedeutung der in der altjüdischen Literatur erhaltenen Äußerungen über Jesum und die ersten Christen sind immer noch viele falsche Ansichten verbreitet".

M. Goldstein, Jesus in the Jewish Tradition, New York 1950; J. Maier, Jesus von Nazareth in der talmudischen Überlieferung, Darmstadt 1982; E. Lipiński, "Pandera and Stada", "Studia Judaica" 11 (2008) nr 2 (22), p. 205-213; Pandera \& Stada and Jehoshua bar Perahya, in: Jezus i chrześcijanie $w$ źródtach rabinicznych: Perspektywa historyczna, społeczna, religijna i dialogowa, „Estetyka i Krytyka” nr 27 (3/2012), ed. K. Pilarczyk - A. Mrozek, Kraków 2012, p. 51-66. 
labeled with a pejorative attitude since the Church humiliated and persecuted Jews $^{4}$. The statement that Jews' negative perception of the image of Jesus and Christianity is a mere consequence of "Christian Anti-Semitism" arouses justified disapproval while indicating at the same time an urgent need for reliable research of the image of Jesus in Talmudic texts ${ }^{5}$.

Some contemporary Jewish researchers give a significant importance to the research of Talmudic passages especially those - including references to Jesus and His followers. Dan Jaffé - a Professor at Bar Ilan University in Ramat Gan in Israel, whose observation are based on detailed studies of Talmudic texts, concludes that the Rabbinic perception of Jesus and His disciples reflects the polemic and conflicts between Judaism and Christianity in the process of strengthening their identity ${ }^{6}$. Jacob Neusner states in the book A Rabbi Talks with Jesus that in some circles of Judaism malicious stories about Jesus in which he is presented as a bastard, a fraud and a magus spreading heresy are propagated. In his opinion, the collection of texts entitled Toledot Yeshu, circulating within the Jewish Diaspora since the Middle Ages as well as Talmudic texts presenting Jesus and His followers in a pejorative way has been an inspiration for this image of Jesus?

Talmudic texts about Jesus and His followers do not constitute a compact block, but they are scattered throughout various treatises. A proper assessment of sources should include the historical context of their coming into being (the Palestinian context and the Babylonian context), which to a large extent shaped the nature and intensity of polemic between Judaism and Christianity. When assessing sources, one should take into

4 J. J. Petuchowski - C. Thoma, Leksykon dialogu chrześcijańsko-żydowskiego, tr. J. Kruczyńska, Warszawa 1995, p. 102. See also: W. Chrostowski, Rabiniczny wizerunek Jezusa i chrześcijaństwa w kontekście dialogu Kościoła z Żydami i judaizmem, in: Jezus i chrześcijanie $w$ źródłach rabinicznych: Perspektywa historyczna, społeczna, religijna i dialogowa, „Estetyka i Krytyka" nr 27 (3/2012), ed. K. Pilarczyk - A. Mrozek, Kraków 2012, p. 350.

5 W. Chrostowski, Rabiniczny wizerunek Jezusa i chrześcijaństwa w kontekście dialogu Kościoła z Żydami i judaizmem, p. 350; M. S. Wróbel, Jezus i Jego wyznawcy w Talmudzie, p. 26.

6 D. Jaffé, Le Talmud et les origins juives du christianisme. Jésus, Paul et les judéo-chrétiens dans la littérature Talmudique, Paris 2007, p. 195.

7 J. Neusner, Rabin rozmawia z Jezusem, Kraków 2010, p. 47-48. About Toledot Jeszu see: J. Iluk, Żydowska politeja i Kościół w Imperium Rzymskim u schyłku antyku, vol. 2: Żydowska antyewangelia. Antyczna tradycja i nowożytne trwanie, Gdańsk 2010; Toledot Jeszu - przekaz talmudyczny o Jezusie i chrześcijanach w żydowskiej recepcji, in: Jezus i chrześcijanie w źródtach rabinicznych: Perspektywa historyczna, społeczna, religijna i dialogowa, „Estetyka i Krytyka” nr 27 (3/2012), ed. K. Pilarczyk - A. Mrozek, Kraków 2012, p. 181-217. 
consideration the fact that Jewish communities in Palestine and Babylon lived in different political and social conditions. Let us now describe briefly this context.

The identity of Palestinian community was shaped under the Roman reign, at the time when Christianity was becoming the dominant religion. In the course of editing the Jerusalem Talmud $\left(3^{\text {rd }}-5^{\text {th }}\right.$ century) all texts that referred in a negative way to Jesus and Christianity were consciously omitted so as to avoid disputes and persecution on the part of Christian rulers. The texts emphasizes the magical power of Yeshu ben Pantera's/Pandera's disciples (ישו כן פנטדא/פנדא), who heal in His name. Jesus' followers are presented as heretics - Minim (מינים), who have abandoned the legitimate faith.

The Babylonian community, on the other hand, developed during the reign of the Sassanids, at the time when Christianity was becoming the object of attacks and persecutions on the part of Persian rulers. The authors of the Babylonian Talmud edited between 5th and 8th century were in a position to freely include any unfriendly traditions towards Yeshu and His disciples. Hence, in the Babylonian Talmud it is possible to find considerably more negative passages regarding Jesus than in the Jerusalem Talmud.

Talmudic texts should not be perceived as worthless legends even when they intentionally do not impart to us historical information about Jesus and Christianity. This is because the passages in question, by definition, do not constitute historical sources regarding Jesus and His disciples. They are rather Rabbinic interpretation of what happened, presented in an unequivocally negative way. In their standpoint, rabbis, refer to descriptions of Canon Gospels as well as to early patristic approaches. Many of Rabbinic texts appear to be well-thought thorough literary responses to the evangelical texts and statements of Early Christian apologists. One can discover, in these texts, the existence of various polemical techniques aimed at persuading Jewish believers to avoid contacts with Christians. In the earlier times, rabbis warned the Jewish community against magic power and the attractiveness of the doctrine advocated by heretics. Subsequent rabbis showed the weakness and stupidity of heretical teaching, whose contradictions and lack of logic were easy to disprove by making use of proper argumentation. Jewish sages wished to prove the superiority of the Rabbinic doctrine, and the biblical presentation offered, over the Christian teaching.

When studying Talmudic passages including references to Jesus and His followers one should take into consideration the purpose of the presented 
texts as well as the intentions of the authors of individual traditions and of the editors responsible for putting these texts in a given context. At the same time one should bear in mind the fact that technical terminology in literary texts is characterized by intense dynamism. Hence, certain concepts can take different meanings depending on the period of time when given passages were edited. It is extremely essential when analysing such concepts as, for example, Nazaratheans (Nocrim - נוצרים) Heretics (Minim - מינים), Gospels (Giljonim - גיליונים), Heretics' writings (Sifrei Minim - סיפרי מינרים). The contents and terminology that can be found in Talmudic passages make it possible to connect New Testament texts from $1^{\text {st }}$ century to subsequent pagan texts (a work by Celsus from the second half of $2^{\text {nd }}$ century A $A \lambda \eta \theta \dot{\eta} \varsigma$ ló yos - "The True Word", which survived in extensive quotations in a work by Origen entitled "Against Celsus"), to texts by apologists and Christian writers (Justin Martyr, Origen, Tertullian, Hieronymus, Eusebius of Caesarea, John Chryzostom, Andrew of Crete, John of Damascus, Epiphanius) as well as to apocryphal writings (the Proto-Gospel of James, the Gospel of Nicodemus, the Gospel of Thomas).

An analysis of historicity of statements contained in Talmudic traditions should take into account both non-Talmudic sources (Qumran writings, the New Testament, apocryphal writings, works by Josephus Flavius, Philo of Alexandria and patristic writings), as well as archaeological discoveries. In studies of the Talmud, one should also take into account various traditions that are, many a time, mutually contradictory. That results from the specificity of getting across Rabbinic teachings in which various opinions on the issue are discussed. They come from different periods of time and can constitute a reaction to topical discussions and polemics. The studies of how various traditions are passed on in the Talmud should take into account the historical context. When analyzing Talmudic passages it is necessary to make a conscious distinction between older sources (from the Tannaitic period) and younger sources (from the Amoraitic period). One must not forget that early traditions passed down through oral transmission are preserved in texts edited later.

When analysing Rabbinic texts referring to Jesus and His followers one should bear in mind the fact that they are the fruit of a long process of tradition, and that the desires and tensions of the final editors are sometimes transferred to the times of the earlier functioning Tannaites or Amorites. Thus, a later historical situation finds its reflection in texts describing earlier 
characters and events ${ }^{8}$. In this case, we are dealing with the phenomenon of the multi-level nature of Rabbinic texts, which results in anachronistic shifting of current historical conditions to earlier times ${ }^{9}$. Talmudic texts do not constitute historical chronicles of Jesus and Christianity, but they are a Rabbinic interpretation of the contents included in the Gospels. The texts are a Rabbinic literary answer to the texts of the New Testament in which Jesus is presented as the true Messiah and the Son of God.

When submitting Talmudic passages containing references to Jesus and His disciples for an analysis one should be aware of numerous interferences by censors (Jewish and Christian) who, since the times of Middle Ages, have been trying, intentionally, to cover up any traces of the presence of the Master of Nazareth and His followers in the Rabbinic message. Either complete 'inconvenient' fragments were removed from successive printed editions or their contents were transformed. However, numerous existing ancient manuscripts, collections of removed texts, 'oral tradition' and editions not subjected to censorship make it possible for us to recreate original Talmudic passages and study them. Although some of them are characterised by late dating (the final editing of the Babylonian Talmud is dated to $7^{\text {th }}-8^{\text {th }}$ century), yet they include old traditions showing the negative and polemical way of perceiving the person of Jesus and His disciples by Rabbinic Judaism. These texts reflect the polemic between Rabbinic Judaism and Christianity, whose beginning date back to as early as the $1^{\text {st }}$ century.

\section{The polemic between the Synagogue and the Church}

Until the destruction of the Jerusalem Temple in 70 A. D. Jewish believers in Jesus had been treated as an integral part of Judaism. They took part in the temple and synagogue cult by observing the laws of halacha. The defeat in the war against the Romans was followed by a transformation of Temple

8 Similar phenomena can also be seen in the Gospel of John. See: J. L. Martyn, History and Theology of the Fourth Gospel, New York 1968.

9 R. Kalmin, Christians and Heretics in Rabbinic Literature of Late Antiquity, "Harvard Theological Review" 87 (1994), p. 155: "Portrayals of minim and Christians in Talmudic sources may tell us much about relations between Jews and Christians in the Persian and Roman empires of late antiquity, but they perhaps tell us more about the desires and prejudices of rabbinic authors and editors". 
Judaism into Rabbinic Judaism. Judaism's drive for the highest possible consolidation, while it was strengthening its own identity, resulted in its firm and hostile attitude towards any heterodox elements, including JudeoChristians. The parting of the roads between Judaism and Christianity was influenced by the increasing number of Christians with a pagan background in the Church, as well as by the formula of the Twelfth Blessing - Birkat Ha-Minim (ברכת המינים) composed in the Jamnia period which - after having been added to the regularly said Prayer of Eighteen Blessings - became an effective means of expelling believers in Christ from the synagogue community. At that time, Christianity was going through a two-aspect process. On the one hand, under the influence of various factors it was gradually cutting itself off from Judaism, while, on the other hand, it was incorporating the Jewish prophetic and theological tradition into its identity.

The center of dispute between Christianity and Rabbinic Judaism boiled down to the person of Jesus of Nazareth ${ }^{10}$ - the Crucified Son of God and the Messiah $^{11}$. Christian perception regarding Jesus as the Son of God destroyed, according to rabbis, the foundation of Jewish monotheism expressed in the Decalogue (Ex 20,3-17; Deut 5,7-22) as well as in the prayer Szema Izrael (Deut 6,4-9) ${ }^{12}$.

Rabbis categorically objected to the attitude of Jesus and His followers towards the Law (the Torah). This attitude was characterized by internalisation contrary to formalism, spiritualisation contrary to ritualization as well as by invocations of the primeval will of God contrary to fossilised tradition ${ }^{13}$.

${ }^{10}$ M. Hengel, The Son of God: The Origin of Christology and the History of Jewish-Hellenistic Religion, London 1976, p. 23-34; C. Setzer, You Invent a Christ! Christological Claims as Points of Jewish - Christian Dispute, "Union Seminary Quarterly Review” 44 (1991), p. 315-328.

${ }^{11}$ J. Neusner, "Varieties of Judaism in the Formative Age", Jewish Spirituality. From the Bible Through the Middle Ages, vol. 1, ed. A. Green, New York 1986, p. 190: "What [the Christians] offered was one messianism in place of another. It was the messianism built upon the paradox of the crucified messiah, the scandal of weakness in place of strength, suffering unto death in place of this worldly victory... But to people who believed the messiah would be a general who would throw off the rule of pagans and lead the people to an age of peace and prosperity, the Christian messiah hanging on the cross proved to be an insufferable paradox".

${ }^{12}$ R. Bauckham, God Crucified: Monotheism and Christology in the New Testament, Grand Rapids 1999, p. 14-37; Monotheism and Christology in the Gospel of John, in: Contours of Christology in the New Testament, ed. R. N. Longenecker, Grand Rapids 2005, p. 148-166; P. Schäfer, The Jewish Jesus: How Judaism and Christianity Shaped Each Other, Princeton \& Oxford 2012, p. 21-54.

${ }^{13}$ M. Rosik, Zarzewie konfliktu między Kościołem a Synagoga (do 135 roku), in: Jezus i chrześcijanie w źródłach rabinicznych: Perspektywa historyczna, społeczna, religijna i dialogowa, 
Evangelical texts clearly indicate the superiority of Jesus' teaching over the laws of the Torah with regard to the observance of Sabbath (Mt 12,2-14; Mk 2,28; Lk 6,1-11), ritual purifications (Mt 15,1-12; Mk 7,2-5; Lk 11,37-41), the kosherness of food (Mt 15,10-20; Mk 7,14-23), divorce (Mt 19,1-9; Mk 10,2-12; Lk 16,18). In the Gospel of John Jesus clearly distances Himself from the Jewish Law addressing the "Jews" about "your Law" (Jn 8,17; 10,34) or about "their Law" (Jn 15,25).

Another important motive of disagreement between Rabbinic Judaism and Christianity was their attitude to the Jerusalem Temple. For the followers of Judaism, the Jerusalem Temple constituted a cultic, social, economic and political center. The temple was the place of God's residence (Szekina Adonai). The texts of the Synoptic Gospels include explicite Jesus' announcement of His destruction of Jerusalem Temple (Mt 24,2; Mk 13,2; Lk 21,6) ${ }^{14}$. A sign of the end of the temple was the tearing of the veil during Jesus' death (Mt 27,51; Mk 15,38; Lk 23,45) ${ }^{15}$. In Jesus' teaching the temple becomes subordinated to the reality of the Kingdom of Heaven: "But I say to you that a greater thing than the Temple is here" (Mt 12,6). It is the community of disciples that is to become the Living Temple, of which, the person of Jesus Christ is the cornerstone (Mk 12,1-12). The hostile attitude of Judaism towards Christians with regard to the temple is shown in accusations aimed at Stephen before his martyrdom (Acts 6,11-15). Stephen himself in his speech presents a critical attitude towards the Jerusalem Temple: "But it was Solomon who built the house for him. 'However, the Most High does not live in houses made by men. As the prophet says:' Heaven is my throne, and the earth is my footstool. What kind of house will you build for me? says the Lord. Or where will my resting place be?" (Acts 7,47-49). A reaction to that is the indignation of Stephen's persecutors and consequently his death by stoning.

The dispute between Rabbinic Judaism and Christianity also concerned the issue of choseness and covenant. Although the foundation of Jewish identity as the Chosen Nation and the People of Covenant is confirmed by the Apostle Paul: "I ask then: Did God reject his people? By no means!...

\footnotetext{
„Estetyka i Krytyka” nr 27 (3/2012), ed. K. Pilarczyk - A. Mrozek, Kraków 2012, p. 80.

${ }^{14}$ L. Gaston, No Stone on Another: Studies in the Significance of the Fall of Jerusalem in the Synoptic Gospels, Leiden 1976.

15 J. P. Heil, The Narrative Strategy and Pragmatics of the Temple Theme in Mark, "Catholic Biblical Quarterly” 59 (1997), p. 76-100; G. Witaszek, Teologia światyni, in: Życie religijne w Biblii, ed. G. Witaszek, Lublin 1999, p. 98-99.
} 
God did not reject his people, whom he foreknew". (Rom 11,1-2), still some New Testament (Mt 21,43; 22,7; Mk 12,9; Gal 6,16), apocryphal (2 Ezra 1,35-40; 2,10-14) and patristic texts (Justin Martyr, Dialogue with Trypho, a Jew, 26) point out the "New Chosen People", "new Israel", which the Church is becoming. Believers in Christ as the Israel of God become heirs to the promises (Gal 3,6-9.29; 4,21-31; Rom 9,6-8) in contrast to Israel according to the flesh $(1$ Cor 10,18). 'A new covenant', which becomes a determinant of the identity of the Primitive Church, is made in the person of Jesus Christ (2 Cor 3,6; Mt 26,28; Mk 14,24). Aspirations to strengthen their own identity both on the part of Christianity and Rabbinic Judaism resulted in a polemic about the status of the "true Israel" (verus Israel) ${ }^{16}$.

A significant point of disagreement between Judaism and Christianity was their missionary attitude towards the pagan world. Judaism associated proselytism with the strict observance of the laws of the Torah, in particular circumcision and Sabbath Judaism ${ }^{17}$. However, Christianity - concentrated more on the person of Jesus rather than on regulations of the Law - did not require converted pagans to undergo circumcision and to strictly observe the Law.

Confrontation and polemic between Rabbinic Judaism and Christianity influenced the severity of expressions and hostility between believers of the Synagogue and the Church. That is the context in which Talmudic texts including a strong Anti-Christian hints should be understood.

\section{Features of Rabbinic anti-Gospel}

Rabbis' knowledge of Jesus and the contents of the Gospels was not only based on oral tradition and folk transmission, but also it might have been supported in evangelical literary compositions in the Syrian language. (The Evangelical Harmony - Diatessaron - composed in $2^{\text {nd }}$ century by Tatian and

${ }^{16}$ W. H. C. Frend, Martyrdom and Persecution in the Early Church, Oxford 1965, p. 178-209; M. Simon, Verus Israel: Étude sur les relations entre chrétiens et juifs dans l'empire romain (135-425), Paris 1964, p. 22-85.

17 J. T. Sanders, Schismatics, Sectarians, Dissidents, Deviants: The First One Hundred Years of Jewish-Christian Relations, Valley Forge 1993, p. 85-89; S. T. Katz, The Rabbinic Response to Christianity, in: The Cambridge History of Judaism. The Late Roman-Rabbinic Period, vol. 4, ed. S. T. Katz, Cambridge 2006, p. 263-264. 
Peshitta - the Syrian translation of the New Testament, which was created at the beginning of 5th century). Christian literature in the Syrian language constituted a sort of a bridge between the Christian and Semitic world ${ }^{18}$.

In Talmudic narratives Rabbis created a specific anti-gospel which was initially transmitted verbally and then written down in various contexts of their works. The aim of this anti-gospel is to challenge the authority of Jesus of Nazareth as the Son of God and the Messiah from the house of David. Rabbinic narratives wish to show in a clear way that Jesus must not usurp any messianic and divine prerogatives. The traces of such a view of Jesus can be seen already in the pages of the Gospels, whereby after the crucifixion and resurrection of Jesus, archpriests and the elders of the people call on the soldiers to present the "Jewish" version of the events: (Mt 28,13-15 “Tell people: His disciples came by night and stole Him away while we were asleep. And if this comes to the governor's ears, we will satisfy him and keep you out of trouble'. So they took the money and did as they were directed; and this story has been spread among the Jews to this day"). The "Jewish gossip" found its continuation in Talmudic texts, which not only concentrated on Jesus' death and fate, but they also referred to His origin, birth and activity.

In these texts Jesus is called Yeshu/Nazarathean/Yeshu Nazarathean (ישו הנצרי), Yeshu ben Pandera/Pantera (ישו כן פנטדא/פנדזא), ben Stada/Stara (בן סטרא/סטדא), Balaam (בלעם), A Certain Person (Pלוני - (מרזי), Bastard (ממזר - (בamzer). The change of Jesus' name from Yeshua Or Yehoshua to Yeshu made by Rabbis has a clearly polemic overtone since the term "Yeshu" can be read as an anagram of the Hebrew words: ימח שמו וזכרו (Imach Szmo Wezichro) which means "Let his name and memory be blotted out".

Jesus' disciples are enumerated by name (James of Kefar Sama, Matai, Nakai, Boni, Necer, Toda) or called: Nazaratheans (נוצרים) and heretics (מינים). Rabbis do not make an effort to quote detailed names of believers in Jesus but they often make references to their stereotypical and symbolic terms. Rabbinic texts also discuss the books of heretics (סיפרי מינים) and the Gospels (Giljonim - גיליונים), whose contents are depreciated, and the books themselves are rejected and doomed to destruction.

${ }^{18}$ W. L. Petersen, Tatian's Diatessaron: Its Creation, Dissemination, Significance, and History in Scholarship, Leiden - New York 1994; M.-É. Boismard, Le Diatessaron: de Tatien à Justin, Paris 1992. 
Based on a literary and historical analysis of passages on Jesus and His believers in the Talmud we can state that Jesus explicite is identified with the cryptogram Ben Pandera/Pantera in the whole Rabbinic literature. In the context of relations between an evangelical text, the Rabbinic tradition and non-Bible sources, the name Ben Pandera/Pantera emerges as an epithet regarding Jesus. This was created by rabbis at the end of $1^{\text {st }}$ century as an answer to the evangelical message on His virginal conception spread by Matthew and Luke (Mt 1,18-25; Lk 1,26-38). The tradition finds its echoes in the writings of a pagan author Celsus, in Christian sources and in later Rabbinic sources of the Palestinian origin (T Hul II,22.23.24; JT AZ II,2; JT Szab XIV,4) and of Babylonian origin (BT Szab 104b; BT Sanh 67a). The name Ben, though it is already common in early Rabbinic sources (T Szab XI,15; T Sanh X,11; JT Szab XII,4; JT Sanh VII,16), is, however, identified with Ben Pandera/Pantera and with Yeshu in later Babylonian sources of the Amorites (BT Szab 104b; BT Sanh 67a). The name Yeshu/Yeshu ha-Nocri appears both in early Rabbinic sources of the Palestinian tradition ( $\mathrm{T} \mathrm{Hul}$ II,22.23.24; JT AZ II,2; JT Szab XIV,4), as well as in the Babylonian tradition (BT AZ 16b-17a; BT Ber 17a-b; BT Sanh 43a-b; BT Sanh 103a; BT Sanh 107b; BT Sanh 43a; BT Git 56b-57a). A comparative analysis of Rabbinic texts makes it possible to identify the cryptograms used by Rabbis. For example, in the passage BT Sanh 67a the both names Ben Pandera and Ben Stada are related to the same person who was hanged on the eve of Passover. The text BT Sanh 43a, describing the same event, clearly identifies the person with Yeshu Ha-Nocri. In the earlier Palestinian tradition included in the Tosefta (T Hul II,24) there is a reference to a meeting of a believer in Jesus, James of Kefar Sekanya, with R. Eliezer in Sepphoris, who is instructed in the 'teaching of heresy' in the name of Yeshu ben Pandera. The teaching is quoted in a parallel passage in the later tradition and it is referred to Yeshu Ha-Nocri (BT AZ 16b-17a).

In Talmudic narratives Jesus and His disciples are presented as persons characterised by sexual promiscuity. Jesus is presented as a bastard (mamzer - ממזר) - the son of Miriam and a Roman soldier named Pantera. As a bastard He is subject to the law contained in the Torah of Moses: Deut 23,3 "No bastard shall enter the assembly of the Lord; even to the tenth generation none of his descendants shall enter the assembly of the Lord". Thus, in the rabbis' depiction, He is excluded from the community of Israel and appears as a person acting from the outside. The evangelical story of 
the virginal conception of Jesus with the Power of the Holy Spirit and His royal descent from the House of David is completely negated in Rabbinic narratives. Talmudic passages about Yeshu Nazarathean, who destroys food in a public way (BT Ber 17a-b; BT Sanh 103a) and has improper thoughts about the she-owner of the inn, which $\mathrm{He}$ is excommunicated for, (BT Sanh 107b; BT Sot 47a) can constitute vivid allusions to sexual abuses. Rabbis were able to find a point of reference for these accusations in canonical evangelical texts, in which Jesus shows merciful attitude towards women of easy virtue ( $\mathrm{Lk} 7,36-50 ; \mathrm{J} 8,1-11)$. Accusations towards Eliezer ben Hyrkanos in BT $A Z 16 \mathrm{~b}-17 \mathrm{a}$ might have related to imputations of his participation in Christian agapae, which were perceived as feasts of orgiastic character. Thus, rabbis in casual terms connected Jesus' sexual abuses to the practice that found its alleged continuation in primitive communities of His disciples.

In Rabbinic texts Jesus and His disciples are met with the accusation of magic and idolatry. In this way, rabbis wish to respond to numerous descriptions of miracles made by Jesus in the pages of the Gospels. The reason for these "deeds" is the magic which Jesus got acquainted with in Egypt and took advantage of it ignobly by deceiving the people of Israel ( $\mathrm{J} 7,12.47)$. The magic is continued by Jesus' disciples, who in His name practice healing and cast out evil spirits. Jesus' claims to be the Messiah and the Son of God are perceived, by rabbis, as the greatest blasphemy that deserves to be punished with eternal hell (BT Sanh 43a; BT Git 56b-57a). In an evangelical description the accusation is clearly made by an archpriest in Mt 26,63-65 "And the high priest said to Him, 'I adjure you by the living God, tell us if you are the Christ, the Son of God?' Jesus said to him: 'You have said so. But I tell you, hereafter you will see the Son of Man seated at the right side of Power, and coming on the clouds of heaven.' Then the high priest tore his robes and said, 'He has uttered blasphemy. Why do we still need witnesses? You have now heard his blasphemy.", Thus, the cult of Jesus as the Messiah and the Son of God practiced by His believers, from the Rabbinic standpoint, is perceived as idolatry. Their belief in His deity and messiahship, in His resurrection, in His presence in the Eucharist and in other sacraments deserves, according to rabbis, to be decisively rejected, and a continuation of this practice deserves to be punished with death (BT Sanh 43a-b). 


\section{Conclusions}

When summing up studies of Jesus and His believers in the Talmud one can come to the conclusion that the Rabbinic image of the Founder of Christianity differs completely from the one presented by the Evangelists. Jesus, in the Gospel tradition, is presented as the Son of God, born of the Virgin Mary, coming from the house of David, teaching the truth, making miracles, suffering because of love to the mankind, lifted up on the wood of the cross, resurrected, sending a Paraclete, ascending to heaven and seated at the right side of the Father. Jesus' whole life is directed at redeeming the mankind and giving it eternal life. Jesus of the Gospels is the Messiah and the Son of God fulfilling the prophecies of the Old Testament, who becomes the Head of the Church - the New Israel - the People of the New Covenant. Through sacraments, Jesus as Emmanuel and Kyrios is present and alive in His Church until the end of the world.

In the Talmud, however, Jesus of Nazareth is presented as a bastard (mamzer - ממזר) born as a result of an adulterous relationship between His mother and her lover named Pantera, as a blasphemer, an idolater, a magus, a lecher and a deceiver of Israel, who was rightly punished with crucifixion. His destiny is hell and the punishment of being boiled in His own excrement. His whole life involved forgery, a departure from the true God and setting up a heretic community, which was destined to be punished with death and end up in hell. Viewed in that way, Talmud texts about Jesus and His believers appear to be an anti-Gospel of sorts, whose aim is to devalue the Master of Nazareth and all of his followers.

The Rabbinic anti-Gospel found in the pages of the Talmud, indicates the anti-Christian hints which results from the polemic between Judaism and Christianity, with regard to the status of verus Israel. Jewish sources, in particular the Babylonian Talmud, through their references to Jesus of Nazareth - to His birth, activity and death, wish to show that the faith of Christians is deprived of any foundation and its observance does not make any sense at all. The attitude is born in the atmosphere of mutual accusations and attacks, which must not be forgotten about in the contemporary dialogue between the Church and the Synagogue. Only in an authentic dialogue can one find their true identity by changing prejudices and negative perception into mutual respect and co-operation. 


\section{Bibliography:}

Boyarin D., Border Lines: The Partition of Judaeo-Christianity, Philadelphia: University of Pennsylvania Press 2004.

Chrostowski W., Rabiniczny wizerunek Jezusa i chrześcijaństwa $w$ kontekście dialogu Kościoła z Żydami i judaizmem, in: Jezus i chrześcijanie w źródłach rabinicznych: Perspektywa historyczna, społeczna, religijna $i$ dialogowa, „Estetyka i Krytyka” nr 27 (3/2012), ed. K. Pilarczyk - A. Mrozek, Kraków: Uniwersytet Jagieloński 2012, p. $341-357$.

Goldstein M., Jesus in the Jewish Tradition, New York: The Macmillan Company 1950.

Goodman M., The Function of Minim in Early Rabbinic Judaism, in: Geschichte-TraditionReflexion. FS M. Hengel, ed. H. Cancik, t. 1, Tübingen: J. C. B. Mohr [Paul Siebeck] 1996, p. 501-510.

Herford R. T., Christianity in Talmud and Midrash, London: Williams \& Norgate 1903.

Hirsch J., Regard Talmudique sur la Tradition Chretienne, Paris: Connaissance et Savoirs 2007.

Iluk J., Żydowska politeja i kościót w Imperium Rzymskim u schyłku antyku, vol. 2. Żydowska antyewangelia: Antyczna tradycja $i$ nowożytne trwanie, Gdańsk: Wydawnictwo Uniwersytetu Gdańskiego 2010.

Instone-Brewer D., Traditions of the Rabbis from the Era of the New Testament, vol. 1-2A, Grand Rapids: William B. Eerdmans Publishing Company 2004.

Instone-Brewer D., Jesus of Nazareth's Trial in the Uncensored Talmud, "Tyndale Bulletin" 62 (2011), p. 269-294.

Jaffé D., Le Judaïsme et l'Avènement du Christianisme. Orthodoxie et Hétérodoxie dans la Literature Talmudique I $^{\text {r-II }}$ siècle, Paris: Cerf 2005.

Jaffé D., Le Talmud et les Origins Juives du Christianisme. Jésus, Paul et les Judéo-chrétiens dans la Littératurs Talmudique, Paris: Cerf 2007.

Kalmin R., "Christians and Heretics in Rabbinic Literature of Late Antiquity", HTR 87 (1994), p. 155-169.

Lipiński E., Pandera and Stada, "Studia Judaica" 11 (2008) nr 2 (22), p. 205-213.

Maier J., Jesus von Nazareth in der talmudischen Überlieferung, Darmstadt: Wissenschaftliche Buchgesellschaf 1978.

Neusner J., Rabbinic Literature and the New Testament: What we Cannot Show we do not Know, Valley Forge: Trinity Press International 1994.

Neusner J., Rabin rozmawia z Jezusem, Kraków: Wydawnictwo M 2010.

Pilarczyk K. - Mrozek A. (eds.), Jezus i chrześcijanie w źródłach rabinicznych: Perspektywa historyczna, spoleczna, religijna i dialogowa, „Estetyka i Krytyka” nr 27 (3/2012), Kraków: Uniwersytet Jagieloński 2012.

Schäfer P., Jesus in the Talmud, Princeton: Princeton University Press 2007.

Schäfer P., The Jewish Jesus: How Judaism and Christianity Shaped Each Other, Princeton \& Oxford: Princeton University Press 2012.

Schiffman L., Who was a Jew?: Rabbinic and Halakhic Perspectives on the Jewish-Christian Schism, Hoboken: Ktav Publishing House, 1985. 
Visotzky B. L., Prolegomenon to the Study of Jewish Christianities in Rabbinic Literature, in: Fathers of the World: Essays in Rabbinic and Patristic Literature, ed. B. L. Visotzky, Tübingen: J. C. B. Mohr [Paul Siebeck] 1995, p. 129-149.

Wróbel M. S., Krytyka tekstologiczna i historyczna passusów Talmudu o Jezusie i chrześcijaństwie, in: Jezus i chrześcijanie w źródłach rabinicznych: Perspektywa historyczna, społeczna, religijna i dialogowa, „Estetyka i Krytyka” nr 27 (3/2012), ed. K. Pilarczyk - A. Mrozek, Kraków: Uniwersytet Jagieloński 2012, p. 15-50.

Wróbel M. S., Jesus and His Followers in the Talmud. A Textological, Historical and Sociological Analysis, Lublin: Wydawnictwo KUL 2013. 